\title{
The correlations among motivation, self-confidence, and speaking ability of the eighth grade students
}

\author{
Suliyati Suliyati ${ }^{1}$, Indawan Syahri ${ }^{2}$ \\ ${ }^{1}$ Madrasah Aliyah Negeri 1 Musi Banyuasin, Indonesia \\ ${ }^{2}$ Universitas PGRI Palembang, Indonesia
}

\section{Article Info}

\section{Article history:}

Received Jul 19 $9^{\text {th }}, 2021$

Revised Aug 10 $0^{\text {th }}, 2021$

Accepted Aug 30 ${ }^{\text {th }}, 2021$

\section{Keyword:}

Motivatoni

Self-confidence

Speaking ability

\begin{abstract}
This study aimed to determine correlation among motivation, self-confidence and speaking ability at the state islamic junior high schools in Musi Banyuasin. The research was conducted correlation research design. This study's population comprised eighth grade studetns of junior high schools in Musi Banyuasin, sampling through a stratified random sampling of 50 students. Data collection techniques used include questionnaire and test. Based on the study results, the data showed that (1) correlation value of 0.885 ; (2) there is not any significant correlation between self-confidence and speaking ability with a correlation value of 0.623 ; (3) there is a significant correlation between motivation and self-confidence with a correlation value of 0.001 (4) there is simultaneous correlation among motivation and self-confidence with speaking ability with correlation value 0.883 , with percentage of $0.5 \%$. Whereas relation $99.5 \%$ is determined by other factors not mentioned in the study.
\end{abstract}

(C) 2021 The Authors. Published by IICET.

This is an open access article under the CC BY-NC-SA license

(https://creativecommons.org/licenses/by-nc-sa/4.0

\section{Corresponding Author:}

Suliyati, S.,

Madrasah Aliyah Negeri 1 Musi Banyuasin, Indonesia

Email: suliyatiandes@gmail.com

\section{Introduction}

Speaking has important role in social life. Speaking is used in society to communicate among people in order to maintain the relationship between them. Speaking involves two or more people that make two-way communication. Speaking is one of the language skills in everyday life used for communication. [1] speaking as "the verbal use of language to speak with others." Speaking may be a productive oral skill usually performed by two or more people.

Speaking is an effective oral skill consisting of standardized verbal utterances that convey meaning. Speaking is the way people relate and express their feelings and opinions [2]. It is very important that we are able to speak correctly. People should speak correctly and clearly, so that they can interact well with each other. It is a must, because without speaking correctly, misunderstandings and issues will occur. Speaking is a very important language skill because it is used to communicate our feelings, to collect data and to receive messages. Speaking is the ability to communicate something through a spoken medium. Speaking is about putting the being communicated. To get contact going well, individuals speak to others. They have to speak out and express their feelings on something. What they need to say if they need to. It helps to know what other individuals want.

Speaking skill is very important for students to effectively communicate through the spoken language. The students' inability to speak a foreign language will make it difficult for them to communicate their thoughts, 
even in simple conversations. One of the key aims of the language learning program is to improve communication skills and to combine written and spoken language. The goal of teaching and learning English is that the students can use the language in real communication. In other word, the students are taught English in order that they are able to communicate in English in their daily life context.

Related with the importance of language skill, it is required to pay great attention to students' speaking ability especially the eighth grade students at the State Islamic Junior High Schools in Musi Banyuasin. Additionally, based on writer's observation speaking English becomes a very difficult thing to do and based on the data students' achievement in English lesson is still low. The data shows that most of the students' score are still below the minimum completeness criteria. Based on eighth grade students competence and indicator for speaking skill, speaking ability eighth grade students at the State Islamic Junior High Schools in Musi Banyuasin is very poor. For example most of students are lack of motivation to learn and not confidence to express their feeling and ideas because they are afraid to make mistake.

[2] the productive domain is the emotional side of human behavior and includes a number of facets of personality, such as emotion, motivation, mood, anxiety, personality, and self-confidence. The statement indicates that motivation is one of the psychological factors which can affect the speaking ability of students. Motivation is something that can improve enthusiasm of the students in learning the language. A teacher should concentrate strongly on the student's reasons for being able to accommodate them. One of the toughest aspects of becoming a teacher is learning how to inspire students. Students with little incentive won't be studying effectively. They're not going to retain details, they're not going to participate and some of them might even get disruptive.

Motivation plays a key role within the lives of individuals, because it provides the causes and roots of human behavior. Motivation is a part of the emotions directly linked to performance. It can make us feel satisfaction or may be greater than the success itself. In one's own life the motivation has immense strength. Motivation is to complete all manner of driving impulses that cause an individual to do something. Motivation is additionally deemed intentional. Whoever wants to do something means he / she is during a motivated state. Any action individuals take is predicated on motivation. People are drinking because they are thirsty, they are sleeping because they are sleepy, and they are talking because they need a thought to precise themselves. Motivation is additionally considered to be intention. Every person's motivation is different but an equivalent we will understand is that the motivation makes them move and live. An individual who has no purpose is just like an individual who doesn't live.

[3] stated that three components of motivation are: commitment (the effort to learn the language), desire (wanting to achieving a goal) and having a positive impact (enjoying the language learning task). Motivation refers to the combination of effort and motivation to accomplish the purpose of language learning, plus optimistic attitudes towards language learning. He believes that fundamental features of predisposition and personality, such as the attitudes of the learner towards foreign people in general and the target group and language in particular, learning motivations and generalized attitudes, affect the desire to learn a foreign language.

Motivation is the important factors in learning process. In other term, the effective learning is influenced by the students' motivation in the classroom, particularly in language classroom. [4] said that In my opinion, the right belief that the passion, dedication and determination of learners are the main determinants of success and failure during the long and sometimes exhausting period of mastering a foreign / second language. It is assumed that the students with high motivation in learning English will be more successful, brave and confidence rather than the students who have low motivation or not at all.

People who are self-confident are those that understand their potential to do something, and then continue to do something like that. Students with self-confidence don't fear expressing their potential. They are generally successful in the classroom, and are not afraid to make mistake in learning.

In essence, self-confidence is an attitude which helps us to possess a positive and realistic view of ourselves and our capabilities. It is characterized by personal attributes like assertiveness, optimism, enthusiasm, affection, pride, independence, trust, the power to handle criticism and emotional maturity [5]. Self-confidence is a personal factor which plays a supporting role in foreign language learning achievement. Some studies claim that is no language learning activities are going to be administered successfully without it. It is going to facilitate or debilitate academic achievement. Learners of foreign languages who have self-confidence do well and presumably think they are competent learners.

In English learning context, speaking English requires high level of self confidence. Students with high level of self-confidence tend not to be shy when speaking. They are quite sure what they are speaking. 
Conversely, students who have low level of confidence are often noticed that they often do not and feel hard to actively communicate and speak in foreign language even in their mother tongue.

Based on the description above the researcher is interested to conduct a research about the correlation among motivation, self confidence and speaking ability of the eighth grade students at the state Islamic junior high schools in Musi Banyuasin.

\section{Method}

This research used quantitative approach and descriptive method to analyze the data that had been collected. A quantitative approach and descriptive method were used in this research because the main purpose of this research is to find out whether there is any correlation among students' speaking anxiety and self-efficacy level and their English-speaking performance or not. In order to find out the correlation, a correlation research design was used in this research.

[6] Explained that, "A correlation research design is a quantitative research method in which the researcher uses the statistical technique of correlation analysis to calculate the degree of association (or relationship) between two or more variables. It can be inferred that a correlation research design enables the researcher to relate two or more variables (students' motivation, self-confidence, and students' speaking ability).

The researcher used this design because she wanted to find out the significant of correlation among motivation, self-confidence and their speaking ability of the eighth grade students at the state islamic junior high schools in Musi Banyuasin. The design as follows:

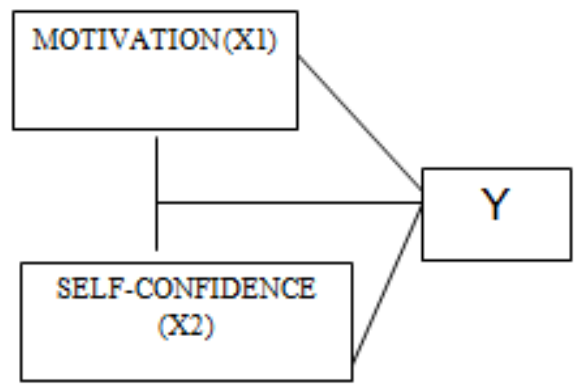

Figure $1<$ Research Design $>$

There are three kinds of variables in this research. The first variable is students' motivation and it is considered as the independent variable (variable X1), the second variable is students' self-confidence and it is also considered as the independent variable (variable X2) and the third is their speaking ability and it is considered as dependent variable (variable y). The researcher used correlational research because it studied about correlation among students' motivation, self-confidence of the eighth grade students at the state Islamic junior high schools in Musi Banyuasin and their speaking ability.

[7] "The population is the larger group to which one hopes to apply the results". Population is that the group of interest to the researcher, the group to whom the researcher would really like to generalize the results of the study. It concludes all the individuals with certain specified characteristic. The population of this study is all the eighth grade students of the State Islamic Junior High Schools in Musi Banyuasin in academic year $2020 / 2021$. The total of population is 499 students but the researcher only took $10 \%$ from the population. So, the sample consists of 50 students. Sampling was done using a stratified random sampling technique.

The research data was collected in two ways. The first is questionnaires which consist of motivation and self-confidence questionnaires. The questionnaires are to determine students' motivation and self-confidence. And the second is speaking test, it is to know students' speaking ability. The questionnaire for motivation is adopted from AMTB (Attitude/Motivation Test Battery) which is designed by [8]. Actually, it consists of 104 items of statements involving attitude and motivation but the researcher only took 30 items from it. The questionnaire for self-confidence is adopted from FLCAS (Foreign Language Classroom Anxiety Scale) [9]. The questionnaire has 33 items about self-confidence, but the researcher only adopted 30 items from it. 


\section{Results and Discussions}

After getting the data from students' motivation, self-confidence, and speaking ability, the researcher conducted the data analysis to find out of normality, homogeneity and Linearity of the data.

In this study, normality test was done by using Kolmogorov Smirnov and calculated by applying SPSS. The significant score was 0.693 . The significant score is higher than 0.05 . Therefore, the data used in this study is normal.Homogeneity test was done by using Levene statistic in SPSS 16 . The significant value of Levene Statistic is 0.270 . This value is higher than 0.05 . Therefore, the data used in this study are homogenous. The result of linearity test shows the significant value of Deviation from Linearity between motivation and speaking ability was 0.861 higher than 0.05 ; it means that two variables had a linear correlation. The result of significant value of linearity test Deviation from Linearity between self-confidence and speaking ability was 0.749 higher than 0.05 ; it means that two variables had a linear correlation.

\section{Hypothesis Test}

1. The Result of Correlation Between Motivation and Speaking Ability.

In order to answer the first research question, the result of motivation and speaking ability through Pearson Product Moment correlation can be seen in Table 1.

Table $1<$ Summary of Correlation between Motivation and Speaking Ability>

\begin{tabular}{llrrr}
\hline & & \multicolumn{2}{c}{ Correlations } & \multicolumn{2}{c}{ Speaking Ability } \\
Motivation & Pearson Correlation & 1 & -.021 \\
& Sig. (2-tailed) & & .885 \\
& $\mathrm{~N}$ & 50 & 50 \\
Speaking & Pearson Correlation & -.021 & 1 \\
Ability & Sig. (2-tailed) & .885 & 50 \\
& $\mathrm{~N}$ & 50 & 50 \\
\hline
\end{tabular}

Based on table 1 above, The result of the correlation coefficient between motivation and speaking ability showed the level of significant was $0.885>0.05$. The result of statistical analysys showed that the values of rx1y $(-0.021)$ and $\mathrm{r} 20.0004(0.04 \%)$. The value of rxly shows that there was a week correlation between motivation and speaking ability. The value of $\mathrm{r} 2$ shows that motivation only contributed $0.04 \%$ to speaking ability. A percentage of $99.96 \%$ was contributed by other factors toward speaking ability. The level of significant was $0.885>0.05$. Consequently, Ha was rejected. It means that between motivation and speaking ability eighth grade students of the State Islamic Junior High Schools in Musi Banyuasin have not a significant correlation. A weak correlation coefficient between motivation and speaking ability indicated that having high motivation does not mean that a student has a good performance in speaking ability.

2. The Result of Correlation between Self-confidence and Speaking Ability

Table $2<$ Summary of Correlation Between Self confidence and Speaking Ability>

\begin{tabular}{llrrr}
\hline & & \multicolumn{2}{c}{ Correlations } & \multicolumn{2}{c}{ Speaking Ability } \\
Self- & Self-confidence & & -.071 \\
confidence & Pearson Correlation & 1 & .623 \\
& Sig. (2-tailed) & & 50 \\
& $\mathrm{~N}$ & 50 & 1 \\
Speaking & Pearson Correlation & -.071 & \\
Ability & Sig. (2-tailed) & .623 & 50 \\
& $\mathrm{~N}$ & 50 &
\end{tabular}

Based on table 2, the result of the correlation coefficient between self- confidence and speaking ability showed that the level of significant was $0.623>0.05$. The result of statistical analysis shows that the values of $r_{x 1 y}(-0.071)$ and $r^{2} 0.005(0.5 \%)$. The value of $r_{x 1 y}$ shows that there was a week correlation 
between self-confidence and speaking ability. The value of $r^{2}$ shows that self-confidence only contributed $0.5 \%$ to speaking ability. A percentage of $99.5 \%$ was contributed by other factors toward speaking ability. The level of significant was $0.623>0.05$. Consequently, Ha was rejected. It means that between self-confidence and speaking ability eighth grade students of the State Islamic Junior High School in Musi Banyuasin have not a significant correlation. A weak correlation coefficient between self-confidence and speaking ability indicated that having high self-confidence does not mean that a student has a good performance in speaking ability.

3. The Result of Correlation Between Motivation and Self-confidence

The analysis of the correlation between motivation and self-confidence used in SPSS 16. The result of the correlation coefficient is presented in the following table.

Table $3<$ Summary of Correlation between Motivation and Self-confidence $>$

\begin{tabular}{|c|c|c|c|}
\hline \multicolumn{4}{|c|}{ Correlations } \\
\hline & & Motivation & Self-confidence \\
\hline \multirow[t]{3}{*}{ Motivation } & Pearson Correlation & 1 & $.467^{* \star}$ \\
\hline & Sig. (2-tailed) & & .001 \\
\hline & $\mathrm{N}$ & 50 & 50 \\
\hline \multirow[t]{3}{*}{ Self-confidence } & Pearson Correlation & $.467^{* *}$ & 1 \\
\hline & Sig. (2-tailed) & .001 & \\
\hline & $\mathrm{N}$ & 50 & 50 \\
\hline
\end{tabular}

**. Correlation is significant at the 0.01 level (2-tailed).

Table 3 showed that P-output was 0.001 . This value was lower than 0.05 . So, it is significant. In this case, Ho was rejected while $\mathrm{Ha}$ was accepted. Therefore, there is a significant correlation between motivation and self-confidence of the eighth grade students at the State Islamic Junior High Schools in Musi Banyuasin.

4. Multiple Regression

Multiple regressions are a statistical tool that allows examining how multiple or sets of independent variables were related to a dependent variable (Higgins, 2005). It will be applied to test whether X1 (Motivation), X2 (Self-confidence) have significant correlation toward variable Y (Speaking Ability). The researcher applied multiple linear regressions with an assistance of SPSS 16. The analysis of multiple regression can be seen below:

Table 4 <The Multiple Linear Regression of Motivation, Self-confidence on Speaking Ability>

\begin{tabular}{|c|c|c|c|c|c|c|}
\hline \multicolumn{7}{|c|}{ ANOVA $^{b}$} \\
\hline Model & Sum of Squares & Df & Mean Square & $\mathrm{F}$ & Sig. & \\
\hline 1 Regression & & & 2 & 10.348 & .124 & $.883^{\mathrm{a}}$ \\
\hline Residual & & & 47 & 83.134 & & \\
\hline Total & & & 49 & & & \\
\hline
\end{tabular}

a. Predictors: (Constant), Self-confidence, Motivation

b. Dependent Variable: Speaking Ability

In relation to table 4 , it was found that p-output is $0.883>0.05$. It is not significant. Therefore Ha3 is rejected while Ho3 is accepted. It means that there are not significant correlations among motivation, self-confidence on speaking ability of the Eighth Grade Students of the State Islamic Junior High School in Musi Banyuasin.

Based on table of output above, it can be seen that the coefficient of determination value or $\mathrm{R}$ Square was 0.005 or equal to $0.5 \%$. It means that motivation variable and self-confidence variable simultaneously affect the speaking ability was only $0.5 \%$. A percentage $99.5 \%$ was contributed by other factors towards speaking ability. $\mathrm{r}$ product moment showed that the correlation between X1, X2 and Y was very weak. It means that there was very weak correlation among motivation, self-confidence and speaking ability. The researcher found that probability value of sig. F Change was $0.883>0.05$, 
consequently, Ha was rejected. It means that motivation, self-confidence and speaking ability have not significant correlation.

Table $5<$ Regression Model Summary $>$

Model Summary

\begin{tabular}{|c|c|c|c|c|c|c|c|c|}
\hline \multirow[b]{2}{*}{ Model } & \multirow[b]{2}{*}{$\mathrm{R}$} & \multirow[b]{2}{*}{ R Square } & \multirow[b]{2}{*}{$\begin{array}{l}\text { Adjusted } \\
\text { R Square }\end{array}$} & \multirow{2}{*}{$\begin{array}{l}\text { Std. Error } \\
\text { of the } \\
\text { Estimate }\end{array}$} & \multicolumn{4}{|c|}{ Change Statistics } \\
\hline & & & & & $\begin{array}{l}\text { R Square } \\
\text { Change }\end{array}$ & $\begin{array}{c}\mathrm{F} \\
\text { Change }\end{array}$ & df1 df2 & Sig. F Change \\
\hline 1 & $.073^{\mathrm{a}}$ & .005 & -.037 & 9.118 & .005 & .124 & 247 & .883 \\
\hline $\begin{array}{l}\text { a. Pred } \\
\text { (Consta } \\
\text { Self- } \\
\text { confide } \\
\text { Motiva }\end{array}$ & $\begin{array}{l}\text { ictors: } \\
\text { ant), } \\
\text { nce, } \\
\text { tion }\end{array}$ & & & & & & & \\
\hline
\end{tabular}

Table $6<$ The Significant of Motivation, Self confidence on Speaking Ability $>$

\begin{tabular}{|c|c|c|c|c|c|c|c|c|}
\hline \multicolumn{9}{|c|}{ Coefficients $^{\mathrm{a}}$} \\
\hline & \multirow[t]{2}{*}{ Model } & \multicolumn{2}{|c|}{$\begin{array}{l}\text { Unstandardized } \\
\text { Coefficients }\end{array}$} & \multirow{2}{*}{$\begin{array}{c}\text { Standardized } \\
\text { Coefficients } \\
\text { Beta }\end{array}$} & \multirow[t]{2}{*}{$\mathrm{t}$} & \multirow[t]{2}{*}{ Sig. } & \multicolumn{2}{|c|}{ Collinearity Statistics } \\
\hline & & $\mathrm{B}$ & Std. Error & & & & Tolerance & VIF \\
\hline \multirow[t]{3}{*}{1} & (Constant) & 72.284 & 13.025 & & 5.550 & .000 & & \\
\hline & Motivation & .012 & .123 & .016 & .096 & .924 & .782 & 1.279 \\
\hline & $\begin{array}{c}\text { Self- } \\
\text { confidence }\end{array}$ & -.049 & .103 & -.079 & -.478 & .635 & .782 & 1.279 \\
\hline
\end{tabular}

a. Dependent Variable: Speaking Ability

Based on table 6 , it showed that the significant value of motivation was 0.924 , which was higher than 0.01 , it means that there was not significant correlation among motivation on speaking ability. And the significant value of self-confidence was 0.635 , which was higher than 0.01 . It means that there was no significant correlation between self-confidence on speaking ability. So, it could be concluded that there was no significant correlation among motivation, self-confidence on speaking ability.

\section{Conclusions}

Based on the results and discussions in the previous chapter, some conclusions could be presented as follows: 1) There is not any significant correlation between motivation and students' speaking ability of the eighth grade students of the State Islamic Junior High Schools in Musi Banyuasin. 2) There is not any significant correlation between self-confidence and students' speaking ability of the eighth grade students of the State Islamic Junior High Schools in Musi Banyuasin. 3) There is a significant correlation between motivation and self-confidence of the eighth grade students of the State Islamic Junior High Schools in Musi Banyuasin.

There are not any significant correlations among motivation, self-confidence and students' speaking ability of the eighth grade students of the State Islamic Junior High Schools in Musi Banyuasin.

\section{References}

Fulcher, G. (2003). Testing Second Language Speaking. Malaysia: Pearson Education Limited.

Nunan, D. (1991). Language Teaching Methodology. Sydney: Macquarie University Press

Lai, T.Y.H. (2013).The motivation of learners of English as a foreign language revisited. International Education Studies,6(10), 91-103.doi.org/10.5539/ies.v6n10p90.

Putra, A. (2017). The correlation between motivation and speaking ability. Channing: Journal of English Language Education and Literature, 2(1), 36-57. https://doi.org/10.30599/channing.v2i1.87, diakses pada tanggal 18 September 2020 pukul 14:30.

Sihera Elaine. (2007). The definition of confidence. (Online). (http://www.elainesden.org, diakses 16 September 2020) 
Creswell, J.W. (2012). Educational Research: Planning, Conducting, and Evaluating Quatitative Research $4^{\text {th }}$ Edition. Upper Saddle River, NJ: Merrill

Fraenkel, et al. (2012). How to Design and Evaluate Research in Education. New York: McGraw-Hill. Inc.

Gardner (2004). The Attitude/Motivation Test Battery: International AMTB Research Project, The University of western Ontario: Canada.

Horwitz, et.al. (1986). Foreign Language Classroom Anxiety. The Modern Language Journal, Vol. 70, No. 2 pp. 125 -132 . 